\title{
Thermodynamic approach to climate change assessment in Pskov
}

\author{
E P Kvachantiradze ${ }^{1, *}$ \\ ${ }^{1} \mathrm{PhD}$ in Biology, professor Russian State Agrarian University - Moscow Timiryazev Agricultural Academy Moscow, Russia
}

\begin{abstract}
Based on the example of Pskov, from the point of view of thermodynamics, climate change was assessed. The results can be used for the environmental and economic rationale for revising the selection of crops for cultivation in the studied area).
\end{abstract}

\section{Introduction}

Today, a sufficient number of various theories are devoted to the causes and consequences of climate warming $[1,2,3,4,5]$. Since the fact of climate warming is indisputable, the reorganization of the agricultural economy naturally acquires the status of paramount importance.

Under conditions of progressive warming of the climate, a high profitability of agricultural production can be achieved provided that the list of crops is constantly adjusted and the forms and doses of fertilizers are chosen to realize the genetic potential of plants in order to obtain the highest yields.

The list of crops is updated on the basis of a statistical method for forecasting the yields, taking into account the trend of climate change. But this method has a significant disadvantage: it characterizes a specific geographic location (according to the limiting environmental factors). The reason for the disadvantage of this method is the assumption of using different units of measurement in the same equation $[6,7,8,9]$.

A unified system of measurements in the prognostic equation will provide an opportunity for a scientific approach to identify patterns in the system "plantenvironment", which will make it possible not to link the further implementation of the prognostic equation to a specific geographic location [10].

A single thermodynamic assessment of the system "plant-environment" was presented in the study $[11,12]$, in which it was proposed to use the enthalpy (heat content) indicators of pure primary photosynthetic production, moist, and moist soil as a single unit of measurement for all members of the equation. Moreover, the enthalpy of pure productivity is the resultant thermodynamic system of moist soil and moist air. Thus, the enthalpy of the soil and the surface layer of air are key elements in the process of the formation of pure primary photosynthetic production.

Thermodynamic assessment of climatic opportunities is the key to the use of resources within the limits, not exceeding the potential renewables, which will make the agricultural economy environmental friendly.

The purpose of the article is to study climate change in Pskov from the perspective of thermodynamics.

\section{Methods and results of the study}

For the period of 1966-2018, based on the hydrometeorological historical data from the source "The Unified State Data Fund" [13], the following indicators were processed: air temperature (annual average, daily average, maximum, minimum), relative air humidity, total precipitation.

The results of the processed data are presented in Table (A-G). For each parameter studied, trend equations were obtained, which describe the average annual and seasonal changes (spring, summer, autumn, winter).

An equation

$$
Y=b_{0}+b_{1} X
$$

where $X$ is year, $b_{0}, b_{1}$ are factors (Table 1$)$.

For each parameter studied, the first and last values in the trend are shown.

The heat content of humid air and the moisture content of the soil are calculated by the start and the end points of the trend of seasonal average daily values of temperature and air humidity. The calculations were carried out according to the described methods [14]. When calculating the soil moisture, the average porosity of Pskov podzolic soils without separation of soil thickness from 0 to $100 \mathrm{~cm}$ was adopted as $42.9 \%$ [15].

Accordingly, the maximum moisture content of the soil, not dependent on the temperature of the soil, but assuming an air temperature of $0{ }^{\circ} \mathrm{C}$ and higher, is equal to the complete filling of the soil pores with water $4290 \mathrm{~m}^{3} / \mathrm{ha}$ or $429 \mathrm{~kg}$ of water per $\mathrm{m}^{3}$ of soil.

The heat content of the soil is calculated on the basis of the predicted soil moisture content and historical soil

\footnotetext{
${ }^{*}$ Corresponding author: eteri.kv@yandex.ru
} 
Table 1. Trend characteristics of the equations of climatic parameters.

\begin{tabular}{|c|c|c|c|c|c|}
\hline $\begin{array}{l}\text { A. Trend of Maximum Temperature, } \\
t_{\max }\end{array}$ & Spring & Summer & Autumn & Winter & Annual average \\
\hline $\mathrm{b}_{0}$ & -60.2294 & -70.37 & -61.4074 & -61.2 & -63.30167198 \\
\hline $\mathrm{b}_{1}$ & 0.038195 & 0.045122 & 0.0323 & 0.030592 & 0.036552267 \\
\hline $\mathrm{t}_{1}{ }^{\max }$ start point, ${ }^{\circ} \mathrm{C}$ & 14.86 & 18.34 & 2.09 & -1.06 & 8.57 \\
\hline $\mathrm{t}_{2}{ }^{\mathrm{max}}$ end point, ${ }^{\circ} \mathrm{C}$ & 16.85 & 20.68 & 3.77 & 0.54 & 10.47 \\
\hline$\Delta \mathrm{t}^{\max }$ & 1.99 & 2.34 & 1.68 & 1.60 & 1.90 \\
\hline B. Trend of $\underset{t}{\min }$ Minimum Temperature, & Spring & Summer & Autumn & Winter & Annual average \\
\hline $\mathrm{b}_{0}$ & -37.6701 & -33.9494 & -42.5491 & -187.731 & -75.47495751 \\
\hline $\mathrm{b}_{1}$ & 0.019583 & 0.023058 & 0.022768 & 0.090256 & 0.038916119 \\
\hline $\mathrm{t}_{1}{ }^{\mathrm{min}}$ start point, ${ }^{\circ} \mathrm{C}$ & 0.83 & 11.38 & 2.21 & -10.29 & 1.03 \\
\hline $\mathrm{t}_{2}{ }^{\mathrm{min}}$ end point, ${ }^{\circ} \mathrm{C}$ & 1.85 & 12.58 & 3.40 & -5.59 & 3.06 \\
\hline$\Delta \mathrm{t}^{\min }$ & 0.98 & 1.20 & 1.19 & 4.70 & 2.03 \\
\hline C. Trend of average daily temperature, $t$ & Spring & Summer & Autumn & Winter & Annual average \\
\hline $\mathrm{b}_{0}$ & -67.1597 & -32.1457 & -40.5746 & -158.709 & -74.6471384 \\
\hline $\mathrm{b}_{1}$ & 0.036551 & 0.024558 & 0.023184 & 0.076984 & 0.04031925 \\
\hline $\mathrm{t}_{1}$ start point, ${ }^{\circ} \mathrm{C}$ & 4.70 & 16.13 & 5.01 & -7.34 & 4.62 \\
\hline $\mathrm{t}_{2}$ end point, ${ }^{\circ} \mathrm{C}$ & 6.60 & 17.41 & 6.21 & -3.35 & 6.72 \\
\hline$\Delta \mathrm{t}$ & 1.90 & 1.28 & 1.20 & 3.99 & 2.10 \\
\hline D. Trend of relative humidity, $\phi$ & Spring & Summer & Autumn & Winter & Annual average \\
\hline $\mathrm{b}_{0}$ & 221.9881 & 28.74986 & 23.28229 & -65.7041 & 52.0790428 \\
\hline $\mathrm{b}_{1}$ & -0.07549 & 0.022582 & 0.031164 & 0.07613 & 0.01359711 \\
\hline$\phi_{1-\text { start point, } \%}$ & 73.58 & 73.15 & 84.55 & 83.97 & 78.81 \\
\hline$\phi_{2}$ - end point, ${ }^{\circ} \mathrm{C}$ & 69.65 & 74.32 & 86.17 & 87.92 & 79.52 \\
\hline$\Delta \phi$ & -3.93 & 1.17 & 1.62 & 3.95 & 0.72 \\
\hline $\begin{array}{l}\text { E. Trend of precipitation (monthly average), } \\
\text { P }\end{array}$ & Spring & Summer & Autumn & Winter & Annual average \\
\hline $\mathrm{b}_{0}$ & -103.176 & -740.262 & 18.85146 & -286.37 & -277.7392515 \\
\hline $\mathrm{b}_{1}$ & 0.073039 & 0.410681 & 0.020373 & 0.164327 & 0.167105005 \\
\hline $\mathrm{P}_{1}$ - start point, $\mathrm{mm} / \mathrm{month}$ & 40.43 & 67.14 & 58.90 & 36.69 & 50.79 \\
\hline $\mathrm{P}_{2-}$ end point, $\mathrm{mm} / \mathrm{month}$ & 44.22 & 88.49 & 59.96 & 45.24 & 59.48 \\
\hline$\Delta \mathrm{P}$ & 3.79 & 21.35 & 1.06 & 8.55 & 8.69 \\
\hline $\begin{array}{c}\text { F. Air enthalpy (daily average) } \\
\text { I kJ / } \mathbf{m}^{3} \text { dry air }\end{array}$ & Spring & Summer & Autumn & Winter & Annual average \\
\hline $\mathrm{I}_{1}-$ start point & 18.91 & 41.75 & 19.32 & -1.37 & 17.66 \\
\hline $\mathrm{I}_{2}$ - end point & 19.93 & 45.34 & 21.54 & 5.11 & 21.80 \\
\hline$\Delta \mathrm{I}$ & 1.02 & 3.59 & 2.22 & 6.48 & 4.14 \\
\hline G. Soil moisture content, g kg / $\mathbf{m}^{3}$ & Spring & Summer & Autumn & Winter & Annual average \\
\hline $\mathrm{g}_{1}-$ start point & 313.7 & 313.9 & 359.6 & - & 338.0 \\
\hline $\mathrm{g}_{2}-$ end point & 299.2 & 316.7 & 358.5 & - & 338.7 \\
\hline$\Delta g$ & -14.5 & 2.8 & -1.1 & - & 0.7 \\
\hline
\end{tabular}

temperature data. However, due to the absence of archival observations of the soil temperature, the heat content of the soil was not calculated.

\section{Discussion of the results}

Air temperature and enthalpy. While discussing the research results, we see that over the study period ( 52 years), the average daily temperature has increased by $2.10{ }^{\circ} \mathrm{C}$ (Table, $\mathrm{C}$ ), which corresponds to the rate of temperature increase of $0.04{ }^{\circ} \mathrm{C}$ per year.

Considering the trends of average daily temperatures for the seasons: spring, summer, autumn, winter we observe that the surface air has become warmer by 1.9 ; 1.28; 1.20 and $4.0{ }^{\circ} \mathrm{C}$, respectively. The main contribution to climate warming is observed in the winter period. Winter is significantly warmer: from -7.34 to $-3.35{ }^{\circ} \mathrm{C}$. The rate of increase in temperature in the winter period of time is substantial, it is $0.077{ }^{\circ} \mathrm{C}$ per year.

We see an explanation of the intense warming of winter not only in increasing the enthalpy of the surface air, but in changing its sign from minus $(-1.37)$ to plus (5.11) and the delta of change is $6.48 \mathrm{~kJ} / \mathrm{m}^{3}$ dry air (Table, F). That is, additional energy has appeared to convert it into heat, and the impact of this energy on the environment is constant every second. The result of this impact is an increase in the minimum winter temperature by $4.7^{\circ} \mathrm{C}$ and for 2018 the minimum temperature does not fall below minus $5.59{ }^{\circ} \mathrm{C}$ (Table, B). The growth of enthalpy is significant in winter, but it is observed in all seasons (Table, F) and the realization of this additional energy is in increasing all temperature characteristics maximum, minimum and average daily values (Table, A; $\mathrm{B}$; C). The additional sum of temperatures for the year by 2018 is $766.5^{\circ} \mathrm{C}$. 
Precipitation and relative humidity. The climate of the Pskov region is shaped under the influence of nearby large water reservoirs and is characterized as moderate continental, humid. The observed slight increase in precipitation and relative humidity (Table, D; E) is associated with an increase in evaporation from nearby large water basins and their precipitation, as a response to global warming. The relative humidity of the air during the crop season spring, summer, autumn has changed slightly: by $-3.93 ; 1.17 ; 1.62 \%$, respectively. Winter has become more humid - relative humidity increased by $3.95 \%$.

Soil moisture content. The total moisture capacity of the soil corresponds numerically to the porosity of the soil, and in our case it is equal to $429 \mathrm{~kg} / \mathrm{m} 3$.

Knowing the total moisture capacity and soil moisture content (Table, G), it is easy to calculate the soil moisture content as a percentage of the total moisture capacity for the seasons. Accordingly, the moisture content as a percentage of the total capacity for the seasons will correspond to $69.74 \%$ in spring; $73.82 \%$ in summer; $83.57 \%$ in autumn, which is a favorable condition for plant growth and development.

Unfortunately, due to the lack of data on soil temperature, the heat content of the soil is not calculated. It can be assumed that the increase in the heat content of the surface air is synchronous with the increase in the heat content of the soil.

\section{Conclusion}

Having studied the dynamics of climate change from the point of view of thermodynamics, we stated the fact of increasing enthalpy, an additional energy that can be converted into heat.

The result of positive enthalpy is climate warming, with the most pronounced effect of enthalpy in the winter period.

The geographical location is characterized by the surrounding large water reservoirs, which under conditions of climate warming, provide a slight increase in precipitation and an increase in air humidity.

By 2018, the increase in temperature has reached $766.5^{\circ} \mathrm{C}$, winter has become significantly warmer, and the summer has become hotter. Against the background of climate warming, soil moisture and air humidity are optimal for most crops.

The nature of trend changes is progressive, which should serve as the basis for revising the choice of crops to ensure the maintenance of an ecological economy.

\section{References}

[1] D. Bhatt, R.K. Mall, Surface Water Resources, Climate Change and Simulation Modelling Aquatic Procedia, 4, 730-738 (2015).

[2] N. Didenko, D. Skripnuk, O. Mirolyubova, Modeling the changes in global temperature due to pollution, International Multidisciplinary Scientific GeoConference Surveying Geology and Mining
Ecology Management, SGEM, 17, 53, 577-586 (2017).

[3] M. Lockwood, Solar Influence on Global and Regional Climates, Survey Geophys, 33, 503-534 (2012).

[4] N. Scafetta, Earth-Science Reviews, 126, 321-357 (2013).

[5] N. Scafetta, Multi-scale Dynamical Analysis (MSDA) of Sea Level Records Versus PDO, AMO, and NAO Indexes. Clim. Dyn., 43, 1-2, 175-192 (2014).

[6] N. Didenko, D. Skripnuk, O. Mirolyubova, M. Radion, Analysis of rural areas development of the region using the ADL-model, Research for Rural Development, 2, 142-214 (2017).

[7] I. Efremova, N. Didenko, D. Rudenko, D. Skripnuk, Disparities in rural development of the Russian Arctic zone regions, Research for Rural Development, 2, 189-194 (2017).

[8] A. Kozlov, S. Gutman, I. Zaychenko, E. Rytova, P. Nijinskaya, Environmental management on the basis of Complex Regional Indicators Concept: Case of the Murmansk region, IOP Conference Series: Materials Science and Engineering, 91, 1, 012073 (2015).

[9] P. Pamukcu, et al., Ecohydrologic modelling of water resources and land use for watershed conservation, Ecological Informatics, 36, 31-41 (2016).

[10] B.E. Bolshakov, E.F. Shamaeva, Systems Analysis of Design and Management of Sustainable Development, Internet journal SCIENCE, 4, 13 (2012) [Electronic resource]. Available at: https://socionet.ru/d/spz:cyberleninka:32385:15650 283/http://cyberleninka.ru/article/n/sistemnyyanaliz-metodov-proektirovaniya-i-upravleniyaustoychivym-razvitiem.

[11] A. Ineson, A.A. Scaife, J.R. Knight, J.C. Manners, N.J. Dunstone, L.J. Grey, J.D. Nature Geos, 4, 11, 753-757 (2011).

[12] E.P. Kvachantiradze, Justification of the cooperation of the world scientific community for the development of a unified thermodynamic system for estimating the condition of phytocenosis, In the journal: Scientific and Creative Heritage of A.V. Chayanov in Agrarian Economy of the XXI Century Materials of the international scientific conference, 167-172 (2018).

[13] Unified state data Fund [Electronic resource]. Available at: http://meteo.ru.

[14] E.P. Kvachantiradze, Basic Climate Forcing Factors from the Thermodynamic Point of View, GEOMED 2016, 4th International Geography Symposium, 23-26 May, Kemer, Antalya, Turkey, 52-61 (2016).

[15] Unified State Register of Soil Resources of Russia, Version 1.0., Ed. By A. Ivanov, S.A. Shobi, ed. V.S. Stolbov, Soils institute named after V.V. Dokuchaev, Russian Agricultural Academy, Tula: Grif and K, 768 (in Russian). 